ARTICLE

\title{
Histone deacetylase inhibitor MS-275 restores social and synaptic function in a Shank3-deficient mouse model of autism
}

\author{
Kaijie Ma ${ }^{1}$, Luye Qin ${ }^{1}$, Emmanuel Matas $\mathbb{D}^{1}$, Lara J. Duffney ${ }^{1}$, Aiyi Liu ${ }^{1}$ and Zhen Yan $\mathbb{D}^{1}$
}

Autism is a neurodevelopmental disorder characterized by social deficits and repetitive behaviors. Genetic screening has identified synaptic, transcriptional, and chromatin genes disrupted in autistic patients. Haploinsufficiency of Shank3, which encodes a scaffold protein at glutamatergic synapses, is causally linked to autism. Using a Shank3-deficient mouse model that exhibits prominent autism-like phenotypes, we have found that histone acetylation in the prefrontal cortex (PFC) is abnormally low, which can be reversed by MS-275 (also known as Entinostat, SNDX-275), a class I histone deacetylase (HDAC) inhibitor that is selectively potent in PFC. A brief (3-day) treatment with MS-275 (i.p.) led to the sustained (11 days) rescue of autistic social preference deficits in Shank3deficient mice, without altering locomotion, motor coordination, anxiety, or the increased grooming. MS-275 treatment also rescued the diminished NMDAR surface expression and NMDAR function induced by Shank3 deficiency. Moreover, F-actin at synapses was restored and the transcription of actin regulators was elevated by MS-275 treatment of Shank3-deficient mice, which may contribute to the recovery of actin-based NMDAR synaptic delivery. Taken together, these results suggest that MS-275 treatment could normalize the aberrant epigenetic regulation of genes, leading to the amelioration of synaptic and social deficits associated with autism.

Neuropsychopharmacology (2018) 43:1779-1788; https://doi.org/10.1038/s41386-018-0073-1

\section{INTRODUCTION}

Autism is a devastating mental disorder that lacks effective treatment [1]. Hundreds of genes have been identified as autism risk factors, many of which are histone-modifying enzymes and chromatin remodelers [2-4]. It raises the possibility that one strategy to reinstate the gene expression pattern and neuronal function in autism is to target epigenetic enzymes. One major epigenetic process essential for gene regulation is histone acetylation and deacetylation catalyzed by histone acetyltransferase (HAT) and histone deacetylase (HDAC) family proteins. HATs and HDACs exert their epigenetic activating or silencing of gene expression via relaxing or condensing the chromatin architecture, respectively. HDACs play a pivotal role in cognitive processes and neurodegenerative diseases [5-7]. Altered histone acetylation and transcriptional dysfunction have been implicated in psychiatric disorders [8-10]. However, the therapeutic potential of HDAC-targeting agents for autism is largely unknown.

Pre-clinical discoveries of therapeutic interventions for autism rely on mouse models that exhibit the prominent "core symptoms" of autism, including deficits in social interactions, communications, and repetitive, restrictive behaviors [11]. Hemizygous deletion or loss-of-function mutation in the Shank3 gene, which encodes a scaffolding protein at glutamatergic synapses $[12,13]$, has been causally linked to human autism and intellectual disability [14-17]. Animal models with the loss of Shank3 exhibit certain autism-related behaviors to different extents [18-25]. Male heterozygous mice with C-terminal (exon 21) deleted Shank3 (Shank3 ${ }^{+/ \Delta C}$ ), which exhibit the significant loss of full-length Shank3 expression, recapitulate pronounced autism-like social preference deficits and repetitive behaviors [18], thus making them an ideal model for the autism drug discovery studies.

The autistic behavioral deficits in Shank $3^{+/ \Delta C}$ mice are attributable to the loss of NMDAR function and synaptic trafficking due to actin dysregulation in pyramidal neurons of prefrontal cortex [18], a key brain region mediating social cognition [26, 27]. In this study, we sought to determine whether histone acetylation is aberrant in Shank3-deficient mice and whether the autism-like synaptic and behavioral deficits can be rescued by MS-275, a potent, long-lasting and frontal cortex-selective HDAC inhibitor [28].

\section{MATERIALS AND METHODS}

The mice expressing C-terminal (exon 21)-deleted Shank3 $\left(\right.$ Shank3 $3^{+/ \Delta C}$, Jackson Labs, Bar Harbor, ME), which exhibited the significant loss of full-length Shank3 expression, were generated and maintained as previously described [18]. Heterozygous Shank $3^{+/ \Delta C}$ mice (6-8 weeks old, male) and age-matched wildtype mice (C57BL/6, male) were used in this study. Mice were group-housed with ad libitum food accessibility in the 12-h light-dark cycle (light: 6 a.m.-6 p.m.; dark: 6 p.m.-6 a.m.). Mice of different genotypes were randomly assigned to drug/saline groups. Experiments were carried out by investigators in a blind fashion (with no prior knowledge about the genotypes and treatments). All experiments were performed with the approval of the Institutional Animal Care and Use Committee of the State University of New York at Buffalo. MS-275 (Selleckchem) was prepared by dissolving in DMSO to make the stock solution and diluting with $0.9 \%$ saline before injections (DMSO concentration of

\footnotetext{
${ }^{1}$ Department of Physiology and Biophysics, State University of New York at Buffalo, Jacobs School of Medicine and Biomedical Sciences, Buffalo, NY 14214, USA
} Correspondence: Zhen Yan (zhenyan@buffalo.edu)

Published online: 19 April 2018 
the working solution: $<0.2 \%)$. All the tests were performed at various days as indicated in the paper after the last injection of the compound.

Behavioral testing

Social preference test. A three-chamber social interaction assay was performed to assess social deficits [18]. Briefly, an apparatus (L: $101.6 \mathrm{~cm}, \mathrm{~W}: 50.8 \mathrm{~cm}, \mathrm{H}: 50.8 \mathrm{~cm}$ ) containing three chambers with retractable doorways allowing for access to side chambers was used. The test was composed of two phases with different stimulus in each of two side chambers. Each stimulus was placed inside a capsule (an inverted pencil cup, D: $10.2 \mathrm{~cm}, \mathrm{H}: 10.5 \mathrm{~cm}$ ). An upright plastic drinking cup was weighed down and placed on top of each capsule to prevent the subject mouse from climbing on top. The first phase contained two identical non-social stimuli (black-folded papers), the second phase contained a non-social (NS) stimulus (a wood block) and a social (Soc) stimulus (mouse of the same strain). Locations of the NS and Soc stimuli were counterbalanced. Animals were habituated in the apparatus for 2 days before testing. During the habituation, two empty capsules were placed at side chambers, and animals were allowed to explore the central chamber for $10 \mathrm{~min}$, followed by an additional 10-min exploration with free access to all three chambers of the apparatus. During the sociability measurement, different stimuli were placed inside capsules at side chambers, and the test animal was placed in the center chamber, and was free to explore the apparatus for $10 \mathrm{~min}$ in each phase, while it was returned to home cage during the 5-min intervals between test phases. The chamber was cleaned with $75 \%$ ethanol after each phase. Interaction time was counted based on "investigating" behaviors of the test animal to each stimulus. In initial experiments, an experimentalist measured the time of the test animal spent on actively seeking and sniffing the stimulus. In later experiments, a computer running the any-maze behavior tracking software (Stoelting, Wood Dale, IL) measured the time of the test animal spent at the close proximity of the capsule (distance of animal head to cup edge: $\leq 3.5 \mathrm{~cm}$ ). Data generated manually and automatically were consistent, so they were pooled together. Preference scores were calculated, where the time spent with one stimulus was subtracted from the time spent with the other stimulus and divided by the total time spent exploring both stimuli.

Locomotion test. Animals were placed in a large cage $(\mathrm{L}: 42 \mathrm{~cm}$, $\mathrm{W}: 20 \mathrm{~cm}, \mathrm{H}: 20 \mathrm{~cm}$ ) devoid of any bedding materials for $5 \mathrm{~min}$ and the number of times crossing a midline was counted.
Rotarod test. To assess motor coordination and balance, an accelerating rotarod (SD instruments, San Diego CA) was used. Mice were placed on a cylinder, which slowly accelerated from 4 to 40 revolutions per minute over a 5 -min test session. The task requires mice to walk forward in order to remain on top of the rotating cylinder rod. Trail 1 and Trail 2 were performed with 2-h interval.

Open field test. Animals were placed in a rectangular arena (60 $\mathrm{cm} \times 80 \mathrm{~cm}$ ); the amount of time the animal spent in the center $(25 \mathrm{~cm} \times 25 \mathrm{~cm})$ was counted. Compared to less anxious counterparts, anxious animals spend less time in center and more time in the corner of the field.

Self-grooming. Mice were scored for spontaneous grooming behaviors when placed individually in a clean cage. The cage was lined with a thin layer of bedding $(\sim 1 \mathrm{~cm})$ in order to reduce neophobia, but prevent digging, a potentially competing behavior. Prior to the testing period, animals were allowed to habituate to the novel environment for $10 \mathrm{~min}$. Each mouse was rated for 10 min on cumulative time spent grooming.

Quantitative real-time RT-PCR

To compare the mRNA levels, quantitative RT-PCR was used. Total RNA was isolated from mouse frontal cortical punches using Trizol reagent (Invitrogen) and treated with DNase I (Invitrogen) to remove genomic DNA. Then, SuperScript III first-strand synthesis system for RT-PCR (Invitrogen) was used to obtain CDNA from the tissue mRNA, followed by the treatment with RNase $\mathrm{H}(2 \mathrm{U} / \mathrm{l})$ for $20 \mathrm{~min}$ at $37^{\circ} \mathrm{C}$. Quantitative real-time RT-PCR was carried out using the $\mathrm{iCycler} \mathrm{iQ}^{\text {TM }}$ Real-Time $\mathrm{PCR}$ Detection System and $\mathrm{iQ}^{\mathrm{TM}}$ Supermix (Bio-Rad) according to the manufacturer's instructions. In brief, GAPDH was used as the housekeeping gene for quantitation of the expression of target genes in samples from WT vs. Shank $3^{+/ \Delta C}$ mice treated with MS-275 or saline control. Fold changes in the target genes were determined by: Fold change $=2^{-\Delta(\Delta C T)}$, where $\Delta C T=C T$ (target) $-\mathrm{CT}(\mathrm{GAPDH})$, and $\Delta$ $(\Delta \mathrm{CT})=\Delta \mathrm{CT}$ (treated group) $-\mathrm{CT}(\mathrm{WT}+$ saline). CT (threshold cycle) is defined as the fractional cycle number at which the fluorescence reaches $10 \times$ the standard deviation of the baseline. A total reaction mixture of $25 \mu \mathrm{l}$ was amplified in a 96-well thin-wall PCR plate (Bio-Rad) using the following PCR cycling parameters: $95^{\circ} \mathrm{C}$ for $5 \mathrm{~min}$ followed by 40 cycles of $95^{\circ} \mathrm{C}$ for $30 \mathrm{~s}, 55^{\circ} \mathrm{C}$ for 30 $\mathrm{s}$, and $72{ }^{\circ} \mathrm{C}$ for $60 \mathrm{~s}$. Primers for all the genes profiled in this study are included in Table 1.

\begin{tabular}{|c|c|c|}
\hline GAPDH & GACAACTCACTCAAGATTGTCAG & ATGGCATGGACTGTGGTCATGAG \\
\hline NR1 & CATCGGACTTCAGCTAATCA & GTCCCCATCCTCATTGAATT \\
\hline NR2A & GGCTACAGAGACTTCATCAG & ATCCAGAAGAAATCGTAGCC \\
\hline NR2B & TTAACAACTCCGTACCTGTG & TGGAACTTCTTGTCACTCAG \\
\hline Rac1 & TAAGGACACCATTGAGAAGC & ATAGCTTCGTCAAACACTGT \\
\hline PAK3 & TGGCTCTTTGACTGATGTG & CCCACCATAGTGCTTCGTTT \\
\hline LIMK1 & AAGAACGTATGGGAGAGGAA & CTTCTCGTAGTACTGGTGTG \\
\hline$\beta \mathrm{PIX}$ & CTGGAGAGACACATGGAGGATT & GTCATTCCTGTTGTTGGCAGCT \\
\hline CTTNBP2 & CGATGTTTCTGACGACTTTG & AAATGTCCCATCTTCCAGAC \\
\hline
\end{tabular}


Primary neuronal culture and transfection

Rat cortical cultures were prepared as described previously [29]. Briefly, frontal cortex was dissected from embryonic day 18 rat embryos, and cells were dissociated using trypsin and trituration through a Pasteur pipette. Neurons were plated on coverslips coated with poly-L-lysine in DMEM with $10 \%$ fetal calf serum at a density of $1 \times 10^{5}$ cells $/ \mathrm{cm}^{2}$. When neurons were attached to the coverslip within $24 \mathrm{~h}$, the medium was changed to neurobasal with B27 supplement (Invitrogen). Cytosine arabinoside (AraC, 5 $\mu \mathrm{M})$ was added at DIV3 to stop glial proliferation. Cultured neurons were transfected with EGFP plus various constructs or siRNA (33.3 nM) using the Lipofectamine 2000 method. Drugs were added 1 day after transfection and electrophysiological recordings were performed on GFP + neurons at 2-3 days after transfection.

Electrophysiological recordings

Whole-cell NMDA-elicited currents in cultured neurons were recorded using standard voltage-clamp techniques [29]. The internal solution contained the following (in $\mathrm{mM}$ ): $180 \mathrm{~N}$-methylD-glucamine, $4 \mathrm{MgCl}_{2}$, 40 HEPES, 0.5 BAPTA, 12 phosphocreatine, 3 $\mathrm{Na}_{2} \mathrm{ATP}$, and $0.5 \mathrm{Na}_{2} \mathrm{GTP}$, pH 7.2-7.3, 265-270 mOsm. The external solution consisted of the following (in $\mathrm{mM}$ ): $127 \mathrm{NaCl}, 20 \mathrm{CsCl}, 1$ $\mathrm{CaCl}_{2}, 5 \mathrm{BaCl}_{2}, 10 \mathrm{HEPES}, 12$ glucose, 0.02 glycine, and 0.001 tetrodotoxin, $\mathrm{pH} 7.4$, and 300 mOsm. Recordings were obtained using Axopatch 200B patch-clamp amplifier (Molecular Devices), controlled with a computer running Clampex 10.2 with a DigiData 1440 A series interface (Molecular Devices). A tight seal (>2G $\Omega$ ) was obtained using negative pressure with membrane disruption after additional suction. The cell membrane was held at $-60 \mathrm{mV}$, and NMDAR-mediated current was elicited by bath application of NMDA $(100 \mu \mathrm{M})$ for $2 \mathrm{~s}$ every $30 \mathrm{~s}$.

Whole-cell voltage-clamp recording technique was used to measure synaptic currents in pyramidal neurons of prefrontal cortical slices as previously described [18]. Mouse slices $(300 \mu \mathrm{m})$ were positioned in a perfusion chamber attached to the fixed stage of an upright microscope (Olympus) and submerged in continuously flowing oxygenated ACSF (in mM: $130 \mathrm{NaCl}, 26$ $\mathrm{NaHCO}_{3}, 1 \mathrm{CaCl}_{2}, 5 \mathrm{MgCl}_{2}, 3 \mathrm{KCl}, 1.25 \mathrm{NaH}_{2} \mathrm{PO}_{4}, 10$ glucose, $\mathrm{pH} 7.4$, $300 \mathrm{mOsm})$. Bicuculline $(20 \mu \mathrm{M})$ and CNQX $(20 \mu \mathrm{M})$ were added in NMDAR-EPSC recordings. Bicuculline and D-APV $(50 \mu \mathrm{M})$ were added in AMPAR-EPSC recordings. Patch electrodes contained internal solution (in $\mathrm{mM}$ ): $130 \mathrm{Cs}$-methanesulfonate, $10 \mathrm{CsCl}, 4$ $\mathrm{NaCl}, 10$ HEPES, $1 \mathrm{MgCl}_{2}$, 5 EGTA, 2 QX-314, 12 phosphocreatine, 5 MgATP, $0.2 \mathrm{Na}_{3} \mathrm{GTP}, 0.1$ leupeptin, pH 7.2-7.3, 265-270 mOsm. Layer 5 medial prefrontal cortex pyramidal neurons were visualized with a $\times 40$ water-immersion lens and recorded with the Multiclamp 700A amplifier (Molecular Devices, Sunnyvale, CA). Evoked EPSC were generated with a pulse from a stimulation isolation unit controlled by a S48 pulse generator (Grass Technologies, West Warwick, RI). A bipolar stimulating electrode (FHC, Bowdoinham, ME) was placed $\sim 100 \mu \mathrm{m}$ from the neuron under recording. For NMDAR-EPSC, the cell (clamped at $-70 \mathrm{mV}$ ) was depolarized to $+40 \mathrm{mV}$ for $3 \mathrm{~s}$ before stimulation to fully relieve the voltage-dependent $\mathrm{Mg}^{2+}$ block. For input-output responses, EPSC was elicited by a series of pulses with different stimulation intensities $(50-90 \mu \mathrm{A})$ delivered at $0.033 \mathrm{~Hz}$. Data analyses were performed with Clampfit (Axon instruments, Molecular Devices, Sunnyvale, CA), Kaleidagraph (Albeck Software, Synergy Software, Reading, PA) and GraphPad Prism 6 (GraphPad Software, Inc., La Jolla, CA).

Biochemical measurement of total, surface, nuclear, and synaptic proteins

Nuclear extracts from mouse brains were prepared as we previously described [30]. Briefly, ten frontal cortical punches (diameter: $2 \mathrm{~mm})$ from fresh mouse slices $(300 \mu \mathrm{m})$ per animal were collected, and then homogenized with $500 \mu \mathrm{l}$ homogenization buffer $(20 \mathrm{mM}$ Tris- $\mathrm{HCl}, \mathrm{pH} 7.4,10 \mathrm{mM} \mathrm{NaCl}, 3$ $\mathrm{mM} \mathrm{MgCl} 2,0.5 \% \mathrm{NP}-40,1 \mathrm{mM}$ PMSF, with cocktail protease inhibitor). The homogenate was incubated on ice for $15 \mathrm{~min}$ and followed by centrifugation at $3000 \times g, 4{ }^{\circ} \mathrm{C}$ for $10 \mathrm{~min}$. The nuclear pellet was resuspended in $50 \mu \mathrm{l}$ nuclear extract buffer $(100 \mathrm{mM}$ Tris- $\mathrm{HCl}, \mathrm{pH} 7.4,100 \mathrm{mM} \mathrm{NaCl}, 1 \mathrm{mM}$ EDTA, 1\% Triton X-100, 0.1\% SDS, $10 \%$ glycerol, $1 \mathrm{mM}$ PMSF, with cocktail protease inhibitor) and incubated on ice for $30 \mathrm{~min}$ with vortex periodically to resuspend the pellet. After centrifugation, the supernatant for nuclear fractions was collected, boiled in $2 \times$ SDS loading buffer for $5 \mathrm{~min}$ and then separated on 10\% SDS-polyacrylamide gels. Western blotting experiments for nuclear proteins were performed with antibodies against acetylated H3K9 (1:1000, Cell Signaling, 9649), H3 (1:500, Cell Signaling Technology, 4499).

The surface NMDA receptors were detected as previously described [31]. In brief, frontal cortical slices were incubated with ACSF containing $1 \mathrm{mg} / \mathrm{ml}$ sulfo- $N$-hydroxysuccinimide-LC-Biotin (Pierce Chemical Co., Rockford, IL) for $20 \mathrm{~min}$ on ice. The slices were then rinsed three times in Tris-buffered saline to quench the biotin reaction, followed by homogenization in modified radioimmunoprecipitation assay buffer. The homogenates were centrifuged at $14,000 \times g$ for $15 \mathrm{~min}$ at $4{ }^{\circ} \mathrm{C}$, incubated with $50 \%$ Neutravidin Agarose (Pierce Chemical Co.) for $2 \mathrm{~h}$ at $4{ }^{\circ} \mathrm{C}$, and bound proteins were resuspended in SDS sample buffer and boiled. Quantitative western blots were performed on biotinylated (surface) proteins. Western blots were performed using antibodies against tubulin (1:5000, Sigma, T9026), NR1 (1:500, NeuroMab, 75272), NR2A (1:500, Millipore, 07-632), and NR2B (1:500, Millipore, 06-600).

Subcellular fractions were prepared as described previously [18]. In brief, blocks of frontal cortex were cut out, weighed, and homogenized in ice-cold lysis buffer $(10 \mathrm{ml} / \mathrm{g}, 15 \mathrm{mM}$ Tris, $\mathrm{pH} 7.6$, $0.25 \mathrm{M}$ sucrose, $1 \mathrm{mM}$ PMSF, $2 \mathrm{mM}$ EDTA, $1 \mathrm{mM}$ EGTA, $10 \mathrm{mM}$ $\mathrm{Na}_{3} \mathrm{VO}_{4}, 25 \mathrm{mM} \mathrm{NaF}, 10 \mathrm{mM}$ sodium pyrophosphate, and protease inhibitor tablet). After centrifugation at $800 \times g$ for $5 \mathrm{~min}$ to remove nuclei and large debris, the remaining supernatant was subjected to $10,000 \times g$ centrifugation for $10 \mathrm{~min}$. The crude synaptosome fraction (pellet) was suspended in lysis buffer containing $1 \%$ Triton $\mathrm{X}-100$ and $300 \mathrm{mM} \mathrm{NaCl}$, homogenized again, and centrifuged at $16,000 \times \mathrm{g}$ for $15 \mathrm{~min}$. Triton-insoluble fraction which mainly includes membrane-associated proteins from synaptosomes was dissolved in 1\% SDS. Samples were boiled in $2 \times$ SDS loading buffer for $5 \mathrm{~min}$, and separated on $7.5 \%$ SDSPAGE. Western blots were performed using antibodies against tubulin (1:5000, Sigma, T9026), PSD95 (1:1000, Cell Signaling, 36233S), and actin (1:1000, Santa Cruz, sc-1616).

Chromatin immunoprecipitation (ChIP)

Briefly, six PFC punches from mouse slices per animal were collected. Each sample was homogenized in $250 \mu \mathrm{l}$ ice-cold douncing buffer $(10 \mathrm{mM}$ Tris- $\mathrm{HCl}, \mathrm{pH} 7.5,4 \mathrm{mM} \mathrm{MgCl}, 1 \mathrm{mM}$ $\left(\mathrm{CaCl}_{2}\right)$. The homogenized sample was incubated with $12.5 \mu \mathrm{l}$ micrococcal nuclease $(5 \mathrm{U} / \mathrm{ml}$, Sigma, N5386) for $7 \mathrm{~min}$ and terminated by adding EDTA at a final concentration of $10 \mathrm{mM}$. Then, hypotonic lysis buffer $(1 \mathrm{ml})$ was added and incubated on ice for $1 \mathrm{~h}$. The supernatant was transferred to a new tube after centrifugation.

After adding 10x incubation buffer (50 mM EDTA, $200 \mathrm{mM}$ Tris$\mathrm{HCl}, 500 \mathrm{mM} \mathrm{NaCl}), 10 \%$ of the supernatant was saved to serve as input control. To reduce nonspecific background, the supernatant was pre-cleared with $100 \mu \mathrm{l}$ of salmon sperm DNA/protein A agarose-50\% slurry (Millipore, 16-157) for $2 \mathrm{~h}$ at $4{ }^{\circ} \mathrm{C}$ with agitation. The pre-cleared supernatant was incubated with antibodies against pan-acetylated H3 (Millipore, 06-599, $7 \mu \mathrm{g}$ per reaction) overnight at $4{ }^{\circ} \mathrm{C}$ under constant rotation, following by incubation with $20 \mu \mathrm{l}$ of Salmon Sperm DNA/Protein A agarose$50 \%$ Slurry for $2 \mathrm{~h}$ at $4{ }^{\circ} \mathrm{C}$. After washing for five times, bound complex was eluted twice from the beads by incubating with the 
A
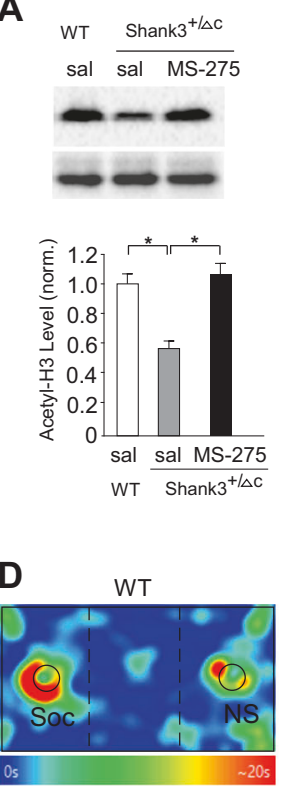

\section{B $\square$ WT+saline}

WT+MS-275

Shank $3^{+/ \Delta C_{+}}+$saline

Shank3 $3^{+/ \Delta C}+$ MS-275

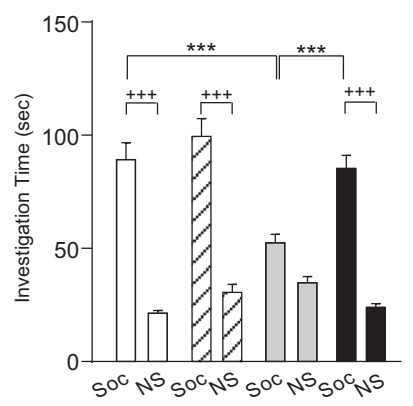

C $\square$ WT+saline

EWT+MS-275

$\square$ Shank $3^{+/ \Delta C}+$ saline

- Shank3 ${ }^{+/ \Delta C}+$ MS-275

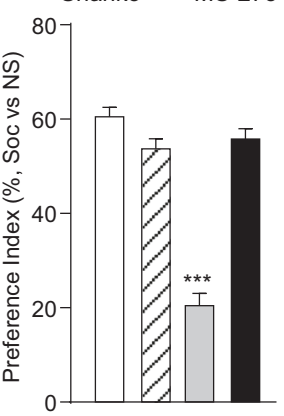

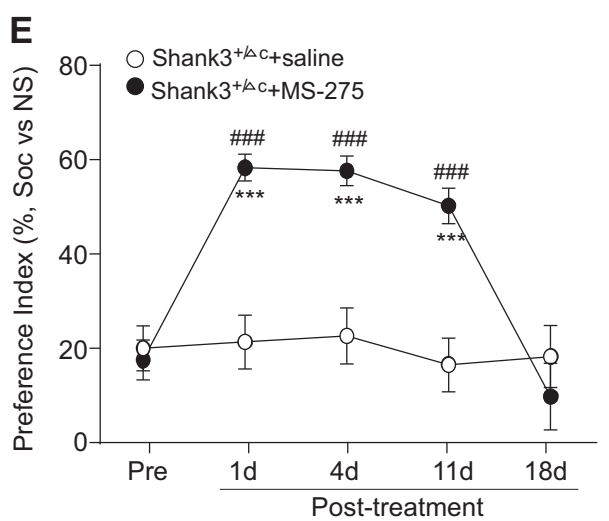

Shank $3^{+/ \Delta c_{+} \text {saline }}$

Shank $3^{+/ \Delta c}+M S-275$
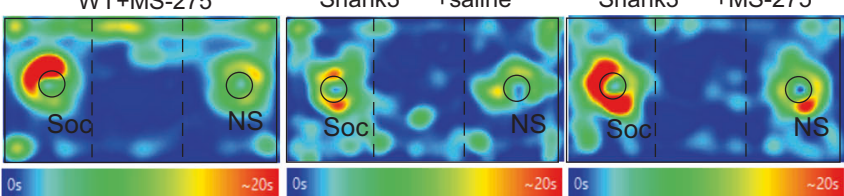

F $\quad \circ \operatorname{MS}-275(0.05 \mathrm{mg} / \mathrm{kg})$

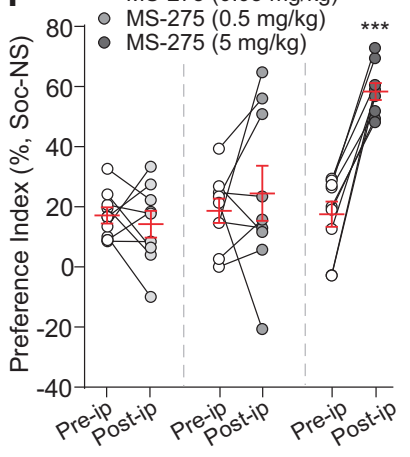

Fig. 1 Treatment with the HDAC inhibitor MS-275 rescues autism-like social deficits in Shank3-deficient mice. a Immunoblots and quantification analysis of the level of acetylated $\mathrm{H} 3$ and total $\mathrm{H} 3$ in the nuclear fraction of cortical slices from WT or Shank3 ${ }^{+/ \Delta C}$ mice treated with MS-275 $(5 \mathrm{mg} / \mathrm{kg}$, i.p., $3 \mathrm{x}$ ) or saline. Immunoblotting was performed at 3-5 days post injection. ${ }^{*} p<0.05$, one-way ANOVA. b Bar graphs showing the time spent investigating either the social (Soc) or non-social (NS) stimulus during three-chamber sociability testing in juvenile male Shank $3^{+/ \Delta C}$ mice or wild-type (WT) mice treated with MS-275 (5 mg/kg, i.p., 3x) or saline. ${ }^{* * *} p<0.001$, saline vs. MS- $275 ;{ }^{+++} p<0.001$, Soc vs. NS, two-way ANOVA. c Bar graphs showing the preference index of the sociability testing in WT or Shank3 ${ }^{+/ \Delta C}$ mice treated with MS-275 or saline. ${ }^{* * *} p<0.001$, two-way ANOVA. d Representative heat maps illustrating the time spent in different locations of the three chambers (blue: $0 \mathrm{~s}$; red: $\sim 20 \mathrm{~s}$ ) from the social preference tests of all groups. Locations of Soc and NS stimuli are labeled with the circles. e Plots of social preference index in Shank3 $3^{+/ \Delta C}$ mice treated with MS-275 $(5 \mathrm{mg} / \mathrm{kg}$, i.p., $3 \mathrm{x})$ or saline at different time points. ${ }^{* * *} p<0.001$, saline vs. MS- 275 ; ${ }^{\# \# \#} p<0.001$, pre- vs. post injection, two-way rmANOVA. f Scatter plots and summary (mean \pm SEM) showing the preference index of the sociability testing in Shank ${ }^{+/ \Delta C}$ mice before and after the treatment with different doses of MS-275 $(0.05,0.5$, and $5 \mathrm{mg} / \mathrm{kg}$, i.p., $3 x) .{ }^{* * *} p<0.001$, paired $t$-test

elution buffer $(100 \mu \mathrm{l})$ at room temperature. Proteins and RNA were removed by using proteinase $\mathrm{K}$ (Invitrogen) and RNase (Roche). Then, immunoprecipitated DNA and input DNA were purified by QIAquick PCR purification Kit (Qiagen). Quantification of ChIP signals was calculated as percent input. Purified DNA was subjected to $\mathrm{qPCR}$ reactions with primers against mouse $\beta P I X$ promoter (Forward, $-950 \mathrm{bp}$ to $-932 \mathrm{bp}$ relative to TSS, $5^{\prime}$ AAACTGTCGAGGAGTGCCAG-3'; Reverse, -749 bp to $-730 \mathrm{bp}$ relative to TSS, 5'- TCAAGAGCACATCGCAACCT-3').

\section{Statistics}

All data were expressed as the mean \pm SEM. No sample was excluded from the analysis. The sample size was based on power analyses and was similar to those reported in previous work [18, $30,31]$. The variance between groups being statistically compared was similar. Each set of the experiments was replicated for at least three times. Experiments with two groups were analyzed statistically using unpaired Student's $t$ tests. Experiments with more than two groups were subjected to one-way ANOVA, twoway ANOVA, or two-way repeated measure ANOVA (rmANOVA), followed by post hoc Bonferroni tests.

\section{RESULTS}

MS-275 treatment exerts the long-lasting rescue of autism-like social deficits in Shank3-deficient mice

To find out potential epigenetic aberrations in autism models, we examined the level of histone acetylation (H3K9Ac) in the prefrontal cortex (PFC) of Shank $3^{+/ \Delta C}$ mice, which exhibited prominent autism-like behavioral deficits [18]. As shown in Fig. 1a, the level of H3K9Ac in the nuclear fraction of PFC slices from Shank $3^{+/ \Delta C}$ mice (saline-injected) was significantly lower than that from wild-type (WT) mice (saline-injected). Systemic administrations of MS-275 (Entinostat) (5 mg/kg, i.p., once daily for 3 days), a 


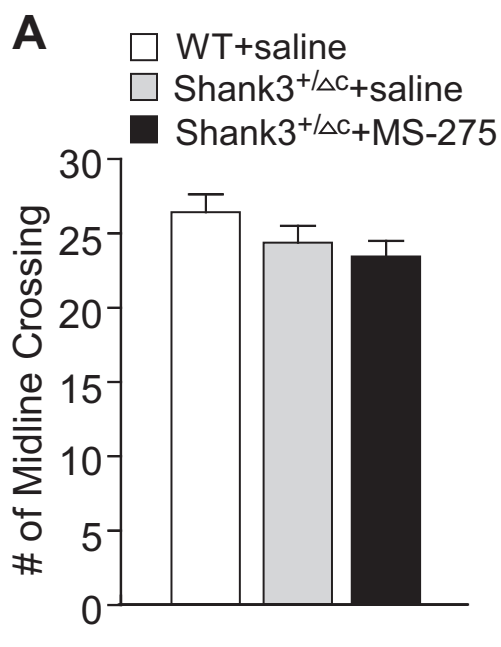

B

B $\square$ WT+saline

$\square$ Shank $3^{+/ \Delta c}+$ saline

- Shank3 $3^{+/ \Delta C}+M S-275$
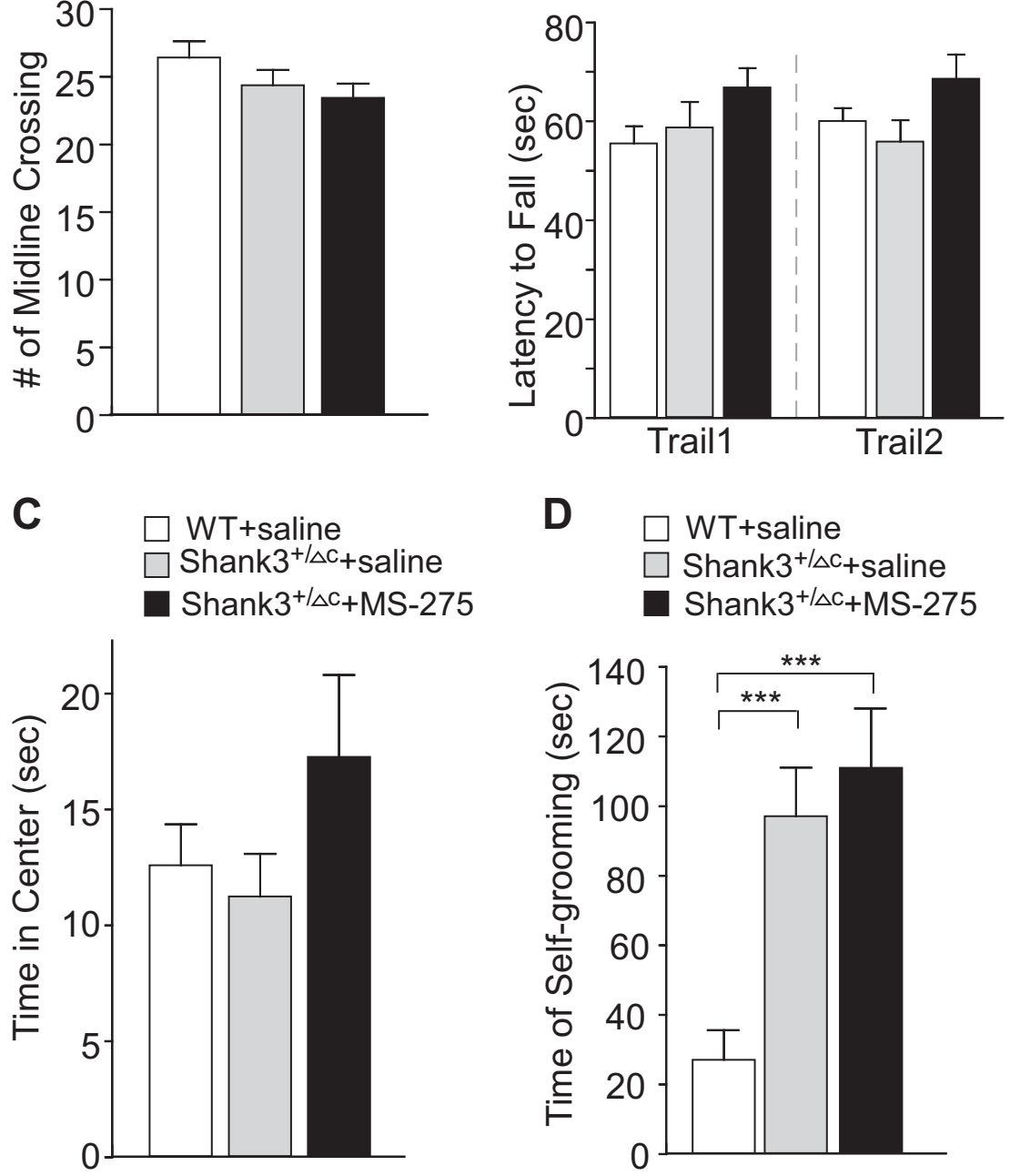

Fig. 2 MS-275 treatment does not alter other behaviors of Shank3-deficient mice. a-d Bar graphs (mean \pm SEM) showing a variety of behaviors in WT, saline-injected Shank3 ${ }^{+/ \Delta C}$ and MS-275 $\left(5 \mathrm{mg} / \mathrm{kg}\right.$, i.p., $3 \mathrm{x}$ )-treated Shank $3^{+/ \Delta C}$ mice, including the number of midline crossing in locomotion tests (a), the latency to fall during two trails of rotarod tests (b), the time spent in the center in open field tests (c), and the time spent self-grooming (d). ${ }^{* * *} p<0.001$, one-way ANOVA

class I HDAC inhibitor [32] that is brain region-selective with the highest potency in PFC [28], significantly reinstated the level of H3K9AC in Shank3 ${ }^{+/ \Delta C}$ mice $\left(n=6\right.$ each group, $F_{2,15}=14.4, p<$ 0.001 , one-way ANOVA), indicating that the abnormally low level of histone acetylation in PFC of Shank3-deficient mice can be restored by MS-275 treatment.

Next, we tested the impact of MS-275 on autism-like social deficits in juvenile male Shank $3^{+/ \Delta C}$ mice using the three-chamber social preference test [11]. As shown in Fig. 1b, during the presentation of both a social (Soc) and a non-social (NS) stimuli, saline-injected WT mice exhibited the strong preference for the social stimulus (Soc: $89.2 \pm 7.5 \mathrm{~s}$, NS: $21.3 \pm 1.3 \mathrm{~s}, n=11, p<0.001$ ), while saline-injected Shank $3^{+/ \Delta C}$ mice showed a significant loss of the social preference (Soc: $52.5 \pm 3.8 \mathrm{~s}$, NS: $34.2 \pm 2.8 \mathrm{~s}, n=15$ ). MS275 treatment of WT mice did not change the social preference (Soc: $99.4 \pm 8.0 \mathrm{~s}$, NS: $30.5 \pm 3.6 \mathrm{~s}, n=10, p<0.001$ ). MS-275treated Shank $3^{+/ \Delta C}$ mice spent significantly more time exploring the social stimulus over the non-social object (Soc: $85.3 \pm 5.7 \mathrm{~s}$, NS: $23.9 \pm 1.7 \mathrm{~s}, n=15, p<0.001, \mathrm{~F}_{3,94}$ (interaction) $=15.3, p<0.0001$, two-way ANOVA). The significantly elevated social preference index in Shank3 ${ }^{+/ \Delta C}$ mice after MS-275 treatment (Fig. 1c, d,
WT: $\quad 60.5 \pm 2.0 \%, \quad n=11 ; \quad$ WT+MS-275: $53.7 \pm 2.2 \%, \quad n=10$; Shank $3^{+/ \Delta C}+$ saline: $20.5 \pm 2.6 \%, \quad n=15 ; \quad$ Shank3 ${ }^{+/ \Delta C}+M S-275$ : $55.8 \pm 2.2 \%, n=15 ; \mathrm{F}_{1,47}$ (interaction) $=79.4, p<0.0001$, two-way ANOVA) suggests that MS-275 induces the dramatic rescue of autism-like social deficits in Shank3-deficient mice.

We further examined how long the rescuing effect of MS-275 treatment $(5 \mathrm{mg} / \mathrm{kg}$, i.p., $3 \times)$ can sustain. The social preference tests were performed in Shank $3^{+/ \Delta C}$ mice prior to and at various time points after drug treatment. As shown in Fig. 1e, the significantly increased social preference index in Shank3 ${ }^{+/ \Delta C}$ mice persisted for at least 11 days post injection of MS-275, while no improvement in social preference was found with repeated measurements of saline-injected Shank $3^{+/ \Delta C}$ mice (MS-275, preip: $17.6 \pm 4.2 \%$, $1 \mathrm{~d}-11 \mathrm{~d}$ post-ip: $50.2-58.3 \%$, $18 \mathrm{~d}$ post-ip: $9.8 \pm$ $7.1 \%, n=9$; saline, pre-ip: $21.3 \pm 4.8 \%, 1 \mathrm{~d}-11 \mathrm{~d}$ post-ip: $16.5-22.6 \%$, 18d post-ip: $18.3 \pm 6.6 \%, n=8 ; F_{1,15}$ (treatment) $=37.3, p<0.001$, $\mathrm{F}_{4,60 \text { (time) }}=11.2, p<0.001$; two-way rmANOVA).

Dose-response studies indicated that lower doses of MS-275 $(0.05 \mathrm{mg} / \mathrm{kg}$ or $0.5 \mathrm{mg} / \mathrm{kg}$, i.p., $3 \times)$ were ineffective in improving the social deficits (Fig. $1 \mathrm{f}, 0.05 \mathrm{mg} / \mathrm{kg}$, pre-ip: $17.2 \pm 2.7 \%$, $1 \mathrm{~d}$ post-ip: $14.2 \pm 4.4 \%, n=9 ; \quad 0.5 \mathrm{mg} / \mathrm{kg}$, pre-ip: $18.7 \pm 4.1 \%$, $1 \mathrm{~d}$ 

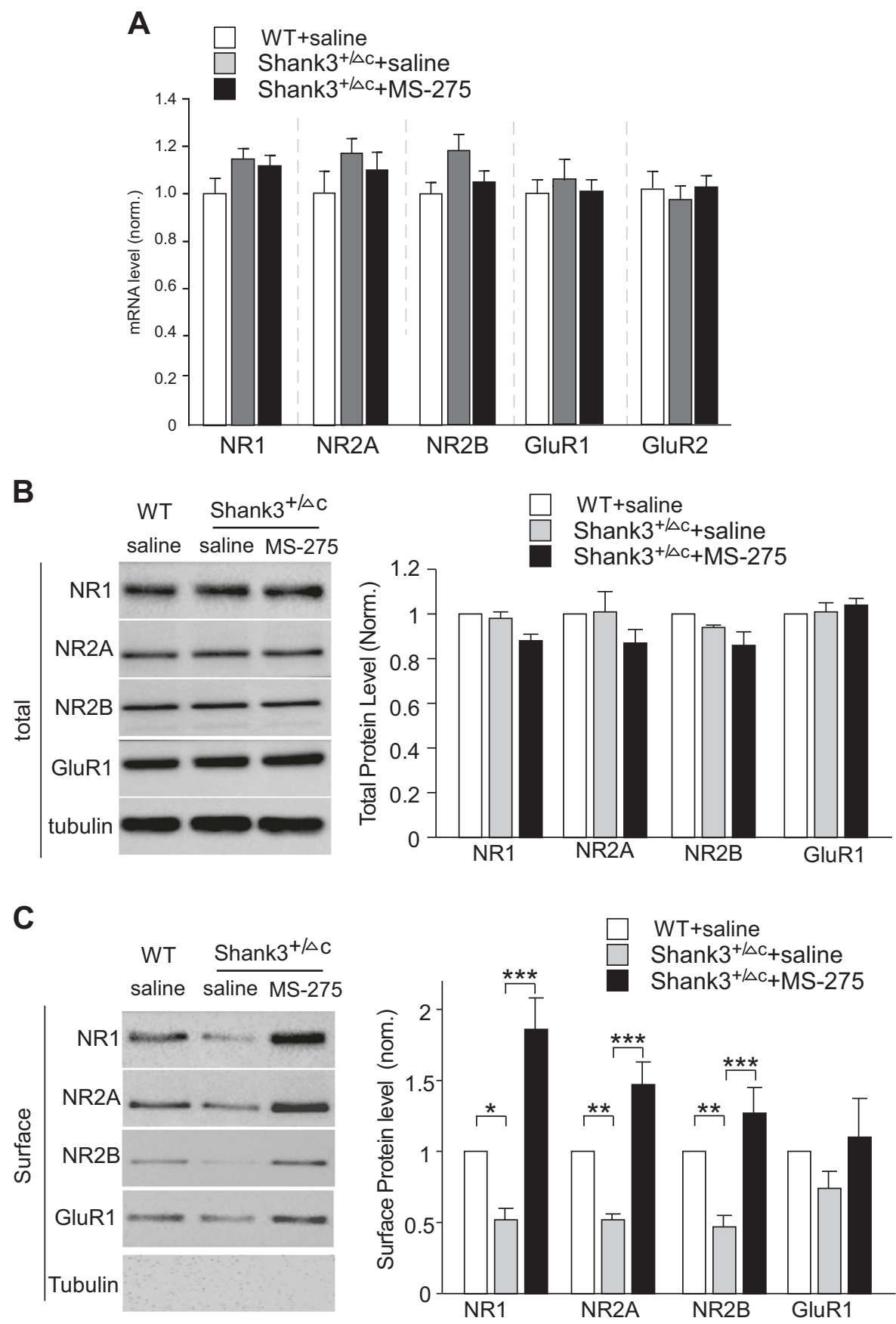

Fig. 3 MS-275 treatment restores NMDAR surface expression in Shank3-deficient mice. a Quantitative real-time RT-PCR data on the mRNA level of NMDAR and AMPAR subunits in PFC slices from WT mice or Shank3 ${ }^{+/ \Delta C}$ mice treated with MS-275 $(5 \mathrm{mg} / \mathrm{kg}$, i.p., $3 x)$ or saline. $\mathbf{b}$, $\mathbf{c}$ Immunoblots and quantification analysis of the total (b) and surface (c) protein level of NMDAR and AMPAR subunits in PFC slices from WT or Shank $3^{+/ \Delta C}$ mice treated with MS-275 or saline. ${ }^{*} p<0.05,{ }^{* *} p<0.01,{ }^{* * *} p<0.001$, one-way ANOVA

post-ip: $24.5 \pm 9.2 \%, n=9, p>0.05$, paired $t$-test), probably because of the limited brain permeability and modest potency of MS-275. The effective dose of MS-275 in rescuing autism-like social deficits, $5 \mathrm{mg} / \mathrm{kg}$ (i.p.), is equivalent to the dose of MS-275 that increases the content of acetyl-H3 in the frontal cortex, 15 $\mu \mathrm{mol} / \mathrm{kg}$ (s.c.) $(5.6 \mathrm{mg} / \mathrm{kg}$ [28]), so this dose of MS-275 was used in the following studies.

A variety of other behaviors were also examined in MS-275treated Shank $3^{+/ \Delta C}$ mice. Compared to wild-type mice or salineinjected Shank3 $3^{+/ \Delta C}$ mice, no differences were observed with MS275 treatment in locomotion tests (Fig. 2a, $n=11-21$ each group,
$\mathrm{F}_{2,43}=1.4, p>0.05$, one-way ANOVA) or rotarod tests (Fig. 2b, $n=$ 12-14 each group, trial 1: $\mathrm{F}_{2,35}=2.0, p>0.05$; trail $2: \mathrm{F}_{2,35}=2.5, p$ $>0.05$, one-way ANOVA), suggesting the normal motor activity and coordination. MS-275- or saline-treated Shank $3^{+/ \Delta C}$ mice spent similar time in the center in open field tests, compared to WT mice (Fig. 2c, $n=11-14$ /each group, $F_{2,36}=0.4, p>0.05$, oneway ANOVA), suggesting the normal anxiety level. MS-275 failed to normalize the increased repetitive grooming in Shank3deficient mice (Fig. 2d, WT: $27.1 \pm 8.5, n=17$, Shank $3^{+/ \Delta C}$ +saline: $97.1 \pm 14, n=21$, Shank3 ${ }^{+/ \Delta C}+M S-275: 111 \pm 17.1, n=11, F_{2,46}=$ $10.9, p<0.001$, one-way ANOVA). 

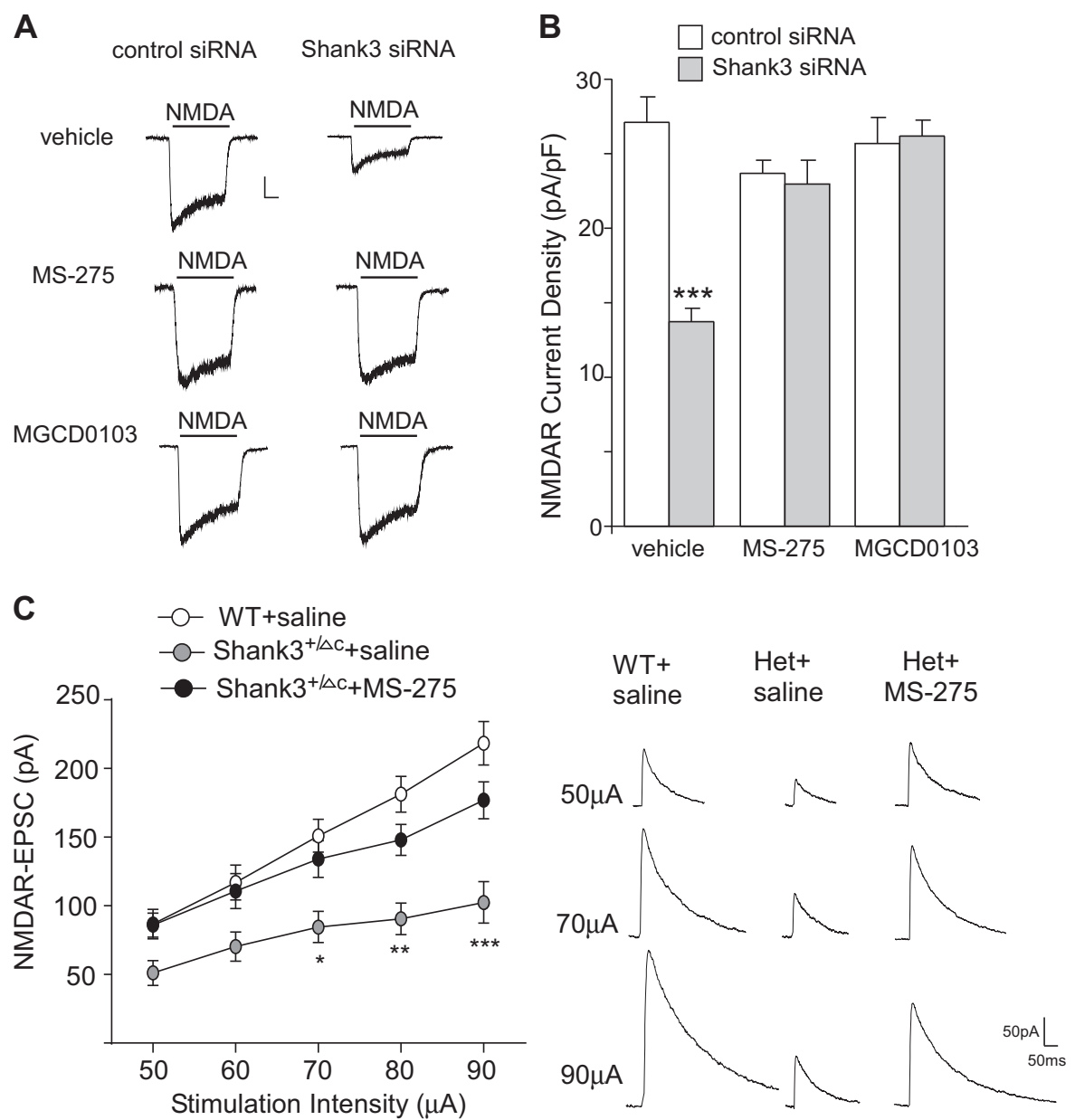

Fig. 4 MS-275 treatment restores NMDAR function in Shank3-deficient mice. a Representative traces of NMDAR-mediated ionic currents in cultured cortical neurons (DIV 21) transfected with control siRNA or Shank3 siRNA treated with MS-275, MGCD0103, or vehicle. Scale bars: 200 $\mathrm{pA}, 0.5 \mathrm{~s}$. b Bar graph summary of the NMDAR current density in cortical cultures with different transfections. ${ }^{* * *} p<0.001, t$-test. c Input-output curves of NMDAR-EPSC in PFC pyramidal neurons from WT vs Shank3 ${ }^{+/ \Delta C}$ mice treated with MS-275 (5 mg/kg, i.p., $3 x$ ) or saline. Recordings were performed at 3-5 days post injection. Inset: representative NMDAR-EPSC traces. ${ }^{*} p<0.05,{ }^{* *} p<0.01,{ }^{* * *} p<0.001$, two-way ANOVA

MS-275 treatment restores NMDAR trafficking and function in Shank3-deficient mice

Next, we sought to find out potential mechanisms underlying the amelioration of autism-like behaviors by HDAC inhibition. Our previous studies have found that the synaptic delivery of NMDARs is significantly reduced in PFC of Shank3-deficient mice, leading to the loss of NMDAR-mediated synaptic responses [18]. Thus, we examined the expression of glutamate receptors in PFC after MS275 treatment. Compared to wild-type mice or saline-injected Shank $3^{+/ \Delta C}$ mice, quantitative $P C R$ analyses showed that the mRNA level of NMDAR subunits (NR1, NR2A, and NR2B) and AMPAR subunits (GluR1 and GluR2) were not significantly changed in Shank3 ${ }^{+/ \Delta C}$ mice treated with MS-275 (5 mg/kg, i.p. 3x) (Fig. 3a, $n=6, p>0.05$, one-way ANOVA). Consistently, the total protein level of glutamate receptor subunits was also unchanged by Shank3 deficiency or MS-275 treatment (Fig. 3b, $n=6-8$ each group, $p>0.05$, one-way ANOVA). However, MS-275 significantly rescued the decreased level of NR1, NR2A, and NR2B subunits at the neuronal surface in Shank3 ${ }^{+/ \Delta C}$ mice (Fig. $3 C$, NR1: WT: $1 \pm$ $0.14, n=6$, Shank $3^{+/ \Delta C}$ +saline: $0.52 \pm 0.08, n=6$, Shank $3^{+/ \Delta C}+$ MS-275: $1.86 \pm 0.22, n=6, \mathrm{~F}_{2,15}=51.0, p<0.001$, one-way ANOVA; NR2A: WT: $1 \pm 0.08, n=7$, Shank $3^{+/ \Delta C}$ saline: $0.52 \pm 0.04, n=7$, Shank $3^{+/ \Delta C}+M S-275: \quad 1.47 \pm 0.16, n=7, F_{2,18}=41.5, p<0.001$, one-way ANOVA; NR2B: WT: $1 \pm 0.1, n=7$, Shank3 $3^{+/ \Delta C}$ +saline: $0.47 \pm 0.08, \quad n=7, \quad$ Shank3 ${ }^{+/ \Delta C}+$ MS-275: $1.27 \pm 0.18, \quad n=6$,
$F_{2,18}=19.6, p<0.001$, one-way ANOVA). It suggests that the disrupted NMDAR trafficking can be restored by MS-275 treatment.

The upregulation of surface NMDARs by MS-275 treatment could ameliorate NMDAR hypofunction induced by Shank3 deficiency. To test this, we first performed in vitro experiments in primary cortical cultures transfected with Shank3 siRNA [29]. As shown in Fig. 4a, b, the NMDA-elicited current density (pA/pF) was significantly decreased by Shank3 knockdown (control siRNA: 27.1 $\pm 1.7, n=6$; Shank3 siRNA: $13.7 \pm 0.9, n=6, p<0.001$, $t$-test), consistent with our previous results [29]. The loss of NMDAR current density was rescued by treatment with MS-275 (control siRNA+MS-275: $23.7 \pm 0.9, n=12$; Shank3 siRNA+MS-275: $23.0 \pm$ $1.6, n=11, p>0.05, t$-test) or another HDAC inhibitor MGCD0103 (control siRNA+MGCD: $25.7 \pm 1.7, n=12$; Shank3 siRNA + MGCD0103: $26.2 \pm 1.1, n=12, p>0.05, t$-test).

We further performed electrophysiological experiments to record NMDAR-mediated excitatory synaptic currents (EPSC) in layer 5 PFC pyramidal neurons, which exhibit the clearest deficits in autistic children [33]. As shown in Fig. 4c, the amplitudes of NMDAR-EPSC induced by a series of stimulus intensities were markedly reduced in saline-injected Shank $3^{+/ \Delta C}$ mice, consistent with our previous findings [18]. A robust recovery of the input/output curves of NMDAR-EPSC was observed in Shank3 $3^{+/ \Delta C}$ mice with MS-275 treatment $(n=8-11$ each group, 

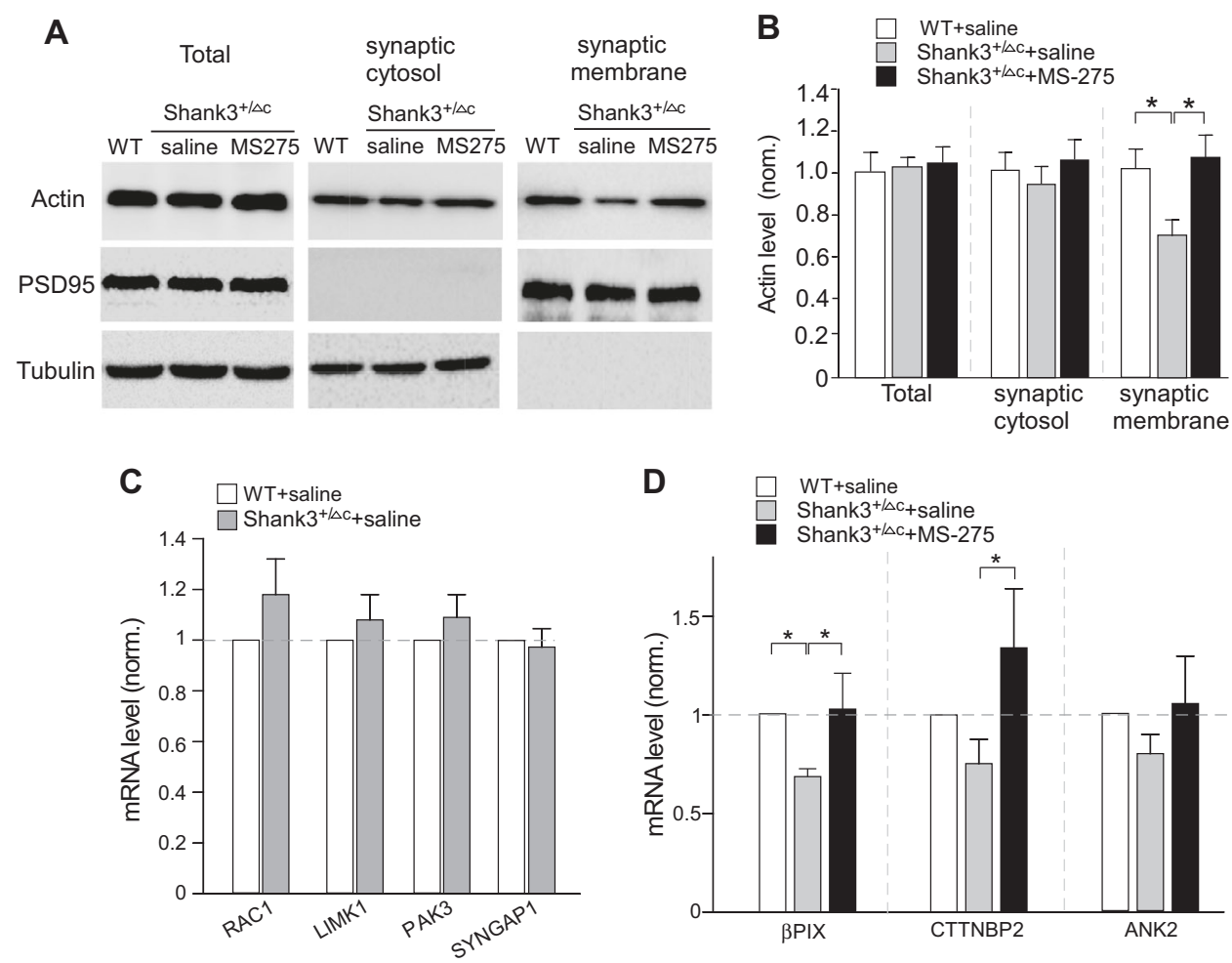

Shank3 ${ }^{+/ \Delta C}+M S-275$
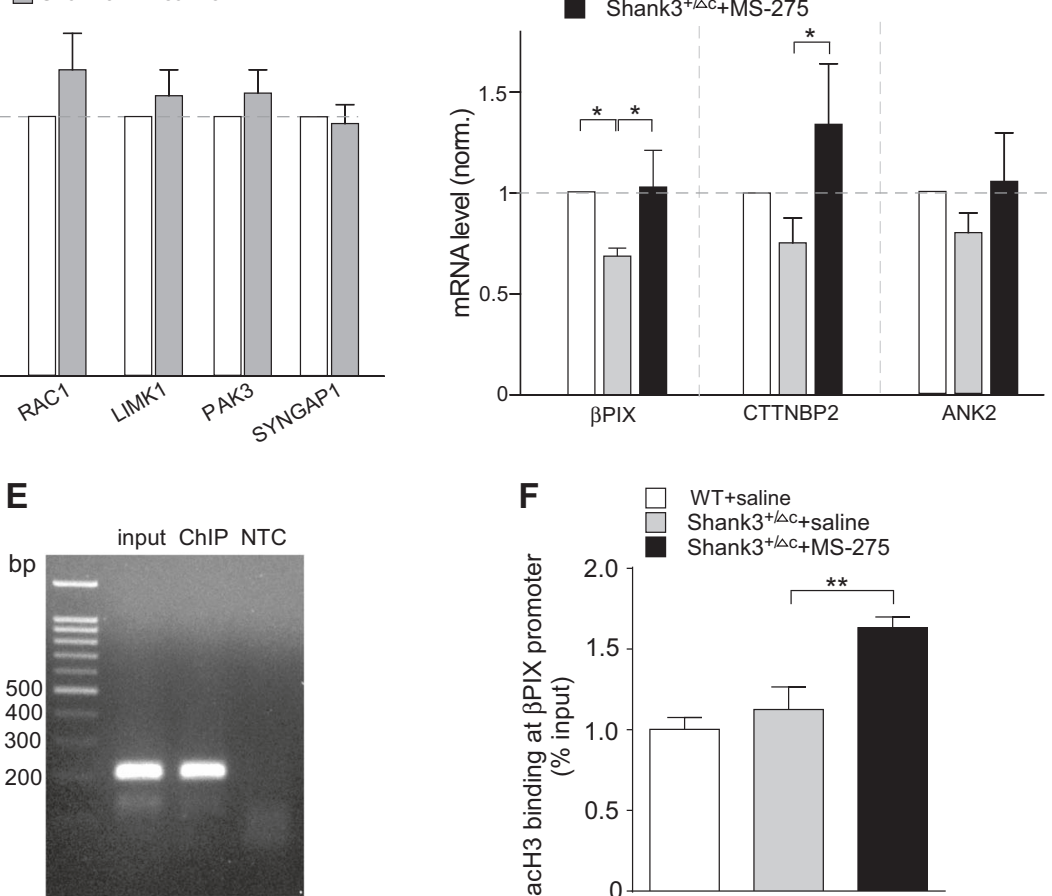

Fig. 5 MS-275 treatment of Shank3-deficient mice restores actin filaments at synaptic membrane and increases the transcription of actin regulators. a, b Immunoblots and quantification (mean \pm SEM) showing actin in the total lysates, triton-soluble synaptic cytosolic fraction (Gactin) and triton-insoluble synaptic membrane fraction (F-actin) in PFC slices from WT mice or Shank3 ${ }^{+/ \Delta C}$ mice treated with MS-275 (5 mg/kg, i.p., $3 \mathrm{x}$ ) or saline. ${ }^{*} p<0.05$, one-way ANOVA. c, d Quantitative RT-PCR data on the mRNA level of actin regulators in PFC slices from WT mice or Shank3 ${ }^{+/ \Delta C}$ mice treated with MS-275 (5 mg/kg, i.p., $\left.3 \mathrm{x}\right)$ or saline. ${ }^{*} p<0.05$, one-way ANOVA. e PCR image showing the input (total DNA), ChIP (AcetyH3-occupied DNA), and no-template control (NTC) signals with a pair of primer designed against the promoter regions of $\beta P I X$. $f$ ChIP assay data showing the acetylated H3 level at $\beta P I X$ promoter in PFC lysates from saline-injected WT, saline-injected Shank3 ${ }^{+/ \Delta C}$, and MS-275treated Shank $3^{+/ \Delta \tau}$ mice. ${ }^{* *} p<0.01$, one-way ANOVA

$F_{2,125}$ (treatment) $=39.8, p<0.001$, two-way ANOVA). The MS-275induced restoration of NMDAR function in PFC may underlie its rescuing effect on autism-like social deficits in Shank3-deficient mice.

MS-275 treatment restores F-actin at synaptic membrane and elevates the transcription of actin regulators in Shank3-deficient mice

The loss of NMDAR-mediated synaptic responses in PFC of Shank3-deficient mice is due to the significantly reduced synaptic F-actin and the disruption of actin-based NMDAR delivery to synapses [18], so we examined the impact of MS-275 on actin filaments at synapses. The level of triton-soluble monomeric actin (G-actin) and triton-insoluble filamentous polymerized actin (Factin) in the synaptic fraction of frontal cortex from WT vs. Shank $3^{+/ \Delta C}$ mice treated with saline or MS-275 were compared. As shown in Fig. 5a,b, the level of synaptic F-actin (insoluble) in
PFC of Shank3 ${ }^{+/ \Delta C}$ mice was significantly lower than WT counterparts, which was restored by MS-275 treatment (WT: $1 \pm 0.1$, Shank3 $3^{+/ \Delta C}+$ saline: $0.69 \pm 0.08$, Shank3 ${ }^{+/ \Delta C}+M S-275: 1.06 \pm 0.11$, $n=6$ each group, $F_{2,15}$ (treatment) $=4.5, p<0.05$, one-way ANOVA). The level of total actin or actin at the synaptic cytosol (soluble) was largely unchanged. It suggests that MS-275 treatment can restore actin filaments at synapses, which may contribute to the recovery of NMDAR trafficking and function in Shank3-deficient mice.

To find out the potential reason for the restoration of F-actin at synapses by MS-275, we examined various actin regulators that could regulate actin dynamics and NMDAR trafficking. It has been found that the Rac1-LIMK-PAK-cofilin signaling is disrupted in Shank3-deficient mice, leading to F-actin dysregulation [18], so we first examined the mRNA level of these genes. As shown in Fig. 5c, the mRNA level of Rac1, LIMK1, and PAK3 was unchanged in PFC of Shank3 ${ }^{+/ \Delta C}$ mice $(n=4-6$ pairs, $p>0.05$, $t$-test), however, $\beta P I X$, 
the guanine nucleotide exchange factor (GEF) for Rac1, which interacts with Shank at excitatory synaptic sites [34], was significantly lost in Shank $3^{+/ \Delta C}$ mice, and MS-275 treatment rescued $\beta P I X$ gene transcription (Fig. $5 \mathrm{~d}, \mathrm{WT}: n=9$, Shank $3^{+/ \Delta C}+$ saline: $n=8$, Shank3 ${ }^{+/ \Delta C}+$ MS-275: $n=4, p<0.05$, ANOVA). The mRNA level of several other Shank3-interacting actin regulators that have been identified as ASD risk factors [3] were also examined. CTTNBP2, which interacts with Cortactin (an F-actin and Shank3-binding protein), was upregulated in Shank3 ${ }^{+/ \Delta C}$ mice treated with MS-275 (Fig. 5d). SYNGAP or Ankyrin2 mRNA was not significantly altered by Shank3 deficiency or MS-275 treatment (Fig. 5c,d). The MS-275-induced restoration or elevation of the transcription of these actin regulators may contribute to the recovery of actin filaments at synapses in Shank3-deficient mice.

Finally, to test the role of histone acetylation in transcriptional regulation by MS-275, we performed ChIP assays to examine the enrichment of histone acetylation at $\beta P I X$ promoter in PFC neurons. $\mathrm{H} 3$ acetylation was identified at $\beta P I X$ promoter region ( 800 bp from TSS, Fig. 5e). MS-275 treatment of Shank $3^{+/ \Delta C}$ mice significantly increased the binding of acetylated $\mathrm{H} 3$ to $\beta P I X$ promoter (Fig. 5f, WT: $1 \pm 0.07, n=6$, Shank3 $3^{+/ \Delta C}+$ saline: $1.13 \pm$ $0.14, n=6$, Shank3 ${ }^{+/ \Delta C}+$ MS-275: $1.63 \pm 0.07, n=8, \mathrm{~F}_{2,17}=13.6, p$ $<0.001$, one-way ANOVA). It suggests that transcriptional increase of $\beta$ PIX by MS-275 could be due to the increased histone acetylation.

\section{DISCUSSION}

Genome-wide exome sequencing has revealed extensive overlap in risk genes for autism and for cancer, many of which are chromatin remodeling factors important for transcriptional regulation [2], raising the possibility of repurposing anti-cancer drugs as targeted treatments for autism [2]. Our present study has provided evidence demonstrating that a single-round (3-day) treatment with MS-275, an anti-cancer agent in clinical trials and a potent, long-lasting and frontal cortex-selective HDAC inhibitor [28], leads to dramatic rescue of autism-like social deficits. The therapeutic effect of MS-275 lasts for more than 10 days during the juvenile to late adolescent period, a critical developmental stage for social and communication skills, making it highly promising for clinical usage. This long-lasting action of MS-275 agrees with pharmacodynamic studies in animals [32], suggesting that this compound may have a slow rate of disappearance from the brain [28]. Furthermore, the lack of behavioral abnormalities after MS-275 treatment indicates the general safety of this compound [35].

To better understand the therapeutic effects of MS-275 on autism-like social deficits, it is important to uncover the molecular mechanism underlying the behavioral normalization. Aberrant synaptic functions are thought to be the main pathological basis of autism [1, 3, 4, 36, 37]. Alterations of glutamatergic synapses have been found in Shank3-deficient mice, which are correlated with autism-like behaviors [18, 20-23, 25]. Particularly, aberrations in NMDA receptor, a Shank3-associated key PSD protein [13, 38], are strongly linked to autistic social deficits $[18,39-41]$. In this study, we have found that MS-275 treatment of Shank3-deficient mice leads to the restoration of NMDAR-mediated synaptic response in PFC, which may underlie the rescue of social behaviors.

The lack of changes in NMDAR subunits by MS-275 treatment suggests that the direct targets of MS-275 are probably NMDAR regulators controlling their synaptic delivery. In vivo Shank3 interactome analysis reveals that many of the Shank3-binding proteins are actin regulators [42]. Enriched mutations in genes regulating actin filament network at glutamatergic synapses have been identified in autism [3, 43]. Our previous studies demonstrate that the Shank3 deficiency-induced NMDAR hypofunction is due to the loss of actin-based synaptic delivery of NMDARs because of the reduced Rac1-PAK-cofilin signaling [18, 29]. Here we have found that the actin filaments in the synaptic membrane of PFC from Shank3-deficient mice are restored by MS-275 treatment. It provides a potential mechanism for the MS-275induced restoration of NMDAR function and social behaviors. Future studies will identify the actin regulators restored by MS-275 treatment that lead to the normalization of F-actin at synapses. Along with the antidepressant-like and ancillary antipsychotic effects of HDAC inhibitors [44-48], our results have added a new domain for the potential utility of HDAC-targeting agents to treat brain disorders.

\section{ACKNOWLEDGEMENTS}

We thank Xiaoqing Chen for her excellent technical support.

\section{FUNDING}

This work was supported by Nancy Lurie Marks Family Foundation and National Institutes of Health (R41-MH112237, R01-MH108842 and R01-DA037618) to ZY.

\section{ADDITIONAL INFORMATION}

Competing interests: The authors declare no competing interests. Z.Y. is the founder of ASDDR LLC.

Publisher's note: Springer Nature remains neutral with regard to jurisdictional claims in published maps and institutional affiliations.

\section{REFERENCES}

1. Delorme R, Ey E, Toro R, Leboyer M, Gillberg C, Bourgeron T. Progress toward treatments for synaptic defects in autism. Nat Med. 2013;19:685-94.

2. Crawley JN, Heyer WD, LaSalle JM. Autism and cancer share risk genes, pathways, and drug targets. Trends Genet. 2016;32:139-46.

3. De Rubeis $S$, He X, Goldberg AP, Poultney CS, Samocha K, et al. Synaptic, transcriptional and chromatin genes disrupted in autism. Nature. 2014;515:209-15.

4. Chen JA, Peñagarikano O, Belgard TG, Swarup V, Geschwind DH. The emerging picture of autism spectrum disorder: genetics and pathology. Annu Rev Pathol. 2015;2015:111-44.

5. Fischer A, Sananbenesi F, Mungenast A, Tsai LH. Targeting the correct HDAC(s) to treat cognitive disorders. Trends Pharmacol Sci. 2010;31:605-17.

6. Gräff J, Rei D, Guan JS, Wang WY, Seo J, Hennig KM, Nieland TJ, Fass DM, Kao PF, Kahn M, Su SC, Samiei A, Joseph N, Haggarty SJ, Delalle I, Tsai LH. An epigenetic blockade of cognitive functions in the neurodegenerating brain. Nature. 2012;483:222-6.

7. Guan JS, Haggarty SJ, Giacometti E, Dannenberg JH, Joseph N, Gao J, Nieland TJ, Zhou Y, Wang X, Mazitschek R, Bradner JE, DePinho RA, Jaenisch R, Tsai LH. HDAC2 negatively regulates memory formation and synaptic plasticity. Nature. 2009;459:55-60.

8. Abel T, Zukin RS. Epigenetic targets of HDAC inhibition in neurodegenerative and psychiatric disorders. Curr Opin Pharmacol. 2008;8:57-64.

9. Grayson DR, Kundakovic M, Sharma RP. Is there a future for histone deacetylase inhibitors in the pharmacotherapy of psychiatric disorders? Mol Pharmacol. 2010;77:126-35.

10. Tsankova N, Renthal W, Kumar A, Nestler EJ. Epigenetic regulation in psychiatric disorders. Nat Rev Neurosci. 2007;8:355-67.

11. Silverman JL, Yang M, Lord C, Crawley JN. Behavioural phenotyping assays for mouse models of autism. Nat Rev Neurosci. 2010;11:490-502.

12. Hayashi MK, Tang C, Verpelli C, Narayanan R, Stearns MH, et al. The postsynaptic density proteins Homer and Shank form a polymeric network structure. Cell. 2009;137:159-71.

13. Naisbitt S, Kim E, Tu JC, Xiao B, Sala C, Valtschanoff J, Weinberg RJ, Worley PF, Sheng M. Shank, a novel family of postsynaptic density proteins that binds to the NMDA receptor/PSD-95/GKAP complex and cortactin. Neuron. 1999;23:569-82.

14. Durand CM, Betancur C, Boeckers TM, Bockmann J, Chaste $P$, et al. Mutations in the gene encoding the synaptic scaffolding protein SHANK3 are associated with autism spectrum disorders. Nat Genet. 2007;39:25-27.

15. Betancur C, Buxbaum JD. SHANK3 haploinsufficiency: a "common" but underdiagnosed highly penetrant monogenic cause of autism spectrum disorders. Mol Autism. 2013:4:17.

16. Leblond CS, et al. Meta-analysis of SHANK mutations in autism spectrum disorders: a gradient of severity in cognitive impairments. PLoS Genet. 2014;10:e1004580. 
17. Bonaglia MC, Giorda R, Borgatti R, Felisari G, Gagliardi C, Selicorni A, Zuffardi O. Disruption of the ProSAP2 gene in a $t(12 ; 22)(q 24.1 ; q 13.3)$ is associated with the 22q13.3 deletion syndrome. Am J Hum Genet. 2001;69:261-8.

18. Duffney LJ, Zhong P, Wei J, Matas E, Cheng J, Qin L, Ma K, Dietz DM, Kajiwara Y, Buxbaum JD, Yan Z. Autism-like deficits in Shank3-deficient mice are rescued by targeting actin regulators. Cell Rep. 2015;11:1400-13.

19. Jiang YH, Ehlers MD. Modeling autism by SHANK gene mutations in mice. Neuron. 2013;78:8-27.

20. Kouser M, Speed HE, Dewey CM, Reimers JM, Widman AJ, et al. Loss of predominant shank3 isoforms results in hippocampus-dependent impairments in behavior and synaptic transmission. J Neurosci. 2013;33:18448-68.

21. Peça J, Feliciano C, Ting JT, Wang W, Wells MF, et al. Shank3 mutant mice display autistic-like behaviours and striatal dysfunction. Nature. 2011;472:437-42.

22. Wang X, Bey AL, Katz BM, Badea A, Kim N, David LK, Duffney L, Kumar S, Mague SD, Hulbert SW, Dutta N, Hayrapetyan V, Yu C, Gaidis E, Zhao S, Ding JD, Xu Q, Chung L, Rodriguiz RM, Wang F, Weinberg RJ, Wetsel WC, Dzirasa K, Yin H, Jiang $\mathrm{YH}$. Altered mGluR5-Homer scaffolds and corticostriatal connectivity in a Shank3 complete knockout model of autism. Nat Commun. 2016;7:11459.

23. Wang X, McCoy PA, Rodriguiz RM, Pan Y, Je S, et al. Synaptic dysfunction and abnormal behaviors in mice lacking major isoforms of Shank3. Hum Mol Genet. 2011;20:3093-108.

24. Bidinosti $M$, Botta $P$, Krüttner $S$, Proenca CC, Stoehr N, Bernhard M, Fruh I, Mueller M, Bonenfant D, Voshol H, Carbone W, Neal SJ, McTighe SM, Roma G, Dolmetsch RE, Porter JA, Caroni P, Bouwmeester T, Lüthi A, Galimberti I. CLK2 inhibition ameliorates autistic features associated with SHANK3 deficiency. Science. 2016;351:1199-203.

25. Bozdagi O, Sakurai T, Papapetrou D, Wang X, Dickstein DL, et al. Haploinsufficiency of the autism-associated Shank3 gene leads to deficits in synaptic function, social interaction, and social communication. Mol Autism. 2010;1:15.

26. Amodio DM, Frith CD. Meeting of minds: the medial frontal cortex and social cognition. Nat Rev Neurosci. 2006;7:268-77.

27. Bicks LK, Koike H, Akbarian S, Morishita H. Prefrontal cortex and social cognition in mouse and man. Front Psychol. 2015;6:1805.

28. Simonini MV, Camargo LM, Dong E, Maloku E, Veldic M, Costa E, Guidotti A. The benzamide MS-275 is a potent, long-lasting brain region-selective inhibitor of histone deacetylases. Proc Natl Acad Sci USA. 2006;103:1587-92.

29. Duffney LJ, Wei J, Cheng J, Liu W, Smith KR, Kittler JT, Yan Z. Shank3 deficiency induces NMDA receptor hypofunction via an actin-dependent mechanism. J Neurosci. 2013;33:15767-78.

30. Wei J, Xiong Z, Lee JB, Cheng J, Duffney $\amalg$, Matas E, Yan Z. Histone modification of Nedd4 ubiquitin ligase controls the loss of AMPA receptors and cognitive impairment induced by repeated stress. J Neurosci. 2016;36:2119-30.

31. Yuen EY, Wei J, Liu W, Zhong P, Li X, Yan Z. Repeated stress causes cognitive impairment by suppressing glutamate receptor expression and function in prefrontal cortex. Neuron. 2012;73:962-77.

32. Saito A, Yamashita T, Mariko Y, Nosaka Y, Tsuchiya K, Ando T, Suzuki T, Tsuruo T, Nakanishi O. A synthetic inhibitor of histone deacetylase, MS-27-275, with marked in vivo antitumor activity against human tumors. Proc Natl Acad Sci USA. 1999;96:4592-7.

33. Stoner R, Chow ML, Boyle MP, Sunkin SM, Mouton PR, Roy S, Wynshaw-Boris A, et al. Patches of disorganization in the neocortex of children with autism. N Engl J Med. 2014:370:1209-19.
34. Park E, Na M, Choi J, Kim S, Lee JR, Yoon J, Park D, Sheng M, Kim E. The Shank family of postsynaptic density proteins interacts with and promotes synaptic accumulation of the beta PIX guanine nucleotide exchange factor for Rac1 and Cdc42. J Biol Chem. 2003;278:19220-9.

35. Fraczek J, Vanhaecke T, Rogiers V. Toxicological and metabolic considerations for histone deacetylase inhibitors. Expert Opin Drug Metab Toxicol. 2013; 9:441-57.

36. Ebrahimi-Fakhari D, Sahin M. Autism and the synapse: emerging mechanisms and mechanism-based therapies. Curr Opin Neurol. 2015;28:91-102.

37. Shcheglovitov A, Shcheglovitova O, Yazawa M, Portmann T, Shu R, Sebastiano V, Krawisz A, Froehlich W, Bernstein JA, Hallmayer JF, Dolmetsch RE. SHANK3 and IGF1 restore synaptic deficits in neurons from 22 q13 deletion syndrome patients. Nature. 2013;503:267-71.

38. Ehlers MD. Synapse structure: glutamate receptors connected by the shanks. Curr Biol. 1999;9:R848-850.

39. Chung W, Choi SY, Lee E, Park H, Kang J, Park H, Choi Y, Lee D, Park SG, Kim R, Cho YS, Choi J, Kim MH, Lee JW, Lee S, Rhim I, Jung MW, Kim D, Bae YC, Kim E. Social deficits in IRSp53 mutant mice improved by NMDAR and mGluR5 suppression. Nat Neurosci. 2015;18:435-43.

40. Won H, Lee HR, Gee HY, Mah W, Kim Jl, et al. Autistic-like social behaviour in Shank2-mutant mice improved by restoring NMDA receptor function. Nature. 2012;486:261-5.

41. Carlson GC. Glutamate receptor dysfunction and drug targets across models of autism spectrum disorders. Pharmacol Biochem Behav. 2012;100:850-4.

42. Han K, Holder JL Jr, Schaaf CP, Lu H, Chen H, et al. SHANK3 overexpression causes manic-like behaviour with unique pharmacogenetic properties. Nature. 2013; 503:72-7.

43. Gilman SR, lossifov I, Levy D, Ronemus M, Wigler M, Vitkup D. Rare de novo variants associated with autism implicate a large functional network of genes involved in formation and function of synapses. Neuron. 2011;70:898-907.

44. Covington HE 3rd, Maze I, LaPlant QC, Vialou VF, Ohnishi YN, Berton O, Fass DM, Renthal W, Rush AJ 3rd, Wu EY, Ghose S, Krishnan V, Russo SJ, Tamminga C, Haggarty SJ, Nestler EJ. Antidepressant actions of histone deacetylase inhibitors. J Neurosci. 2009;29:11451-60.

45. Golden SA, Christoffel DJ, Heshmati M, Hodes GE, Magida J, Davis K, Cahill ME, Dias C, Ribeiro E, Ables JL, Kennedy PJ, Robison AJ, Gonzalez-Maeso J, Neve RL, Turecki G, Ghose S, Tamminga CA, Russo SJ. Epigenetic regulation of RAC1 induces synaptic remodeling in stress disorders and depression. Nat Med. 2013;19:337-44.

46. Kurita M, Holloway T, García-Bea A, Kozlenkov A, Friedman AK, Moreno JL, Heshmati M, Golden SA, Kennedy PJ, Takahashi N, Dietz DM, Mocci G, Gabilondo AM, Hanks J, Umali A, Callado LF, Gallitano AL, Neve RL, Shen L, Buxbaum JD, Han MH, Nestler EJ, Meana JJ, Russo SJ, González-Maeso J. HDAC2 regulates atypical antipsychotic responses through the modulation of mGlu2 promoter activity. Nat Neurosci. 2012;15:1245-54.

47. Schroeder FA, Lin CL, Crusio WE, Akbarian S. Antidepressant-like effects of the histone deacetylase inhibitor, sodium butyrate, in the mouse. Biol Psychiatry. 2007;62:55-64.

48. Tsankova NM, Berton O, Renthal W, Kumar A, Neve RL, Nestler EJ. Sustained hippocampal chromatin regulation in a mouse model of depression and antidepressant action. Nat Neurosci. 2006:9:519-25. 